DOI https://doi.org/10.18551/rjoas.2018-12.34

\title{
ANALYSIS OF AGRIBUSINESS FACTORS OF DAIRY CATTLE IN RELATION TO THE IMPROVEMENT OF MILK PRODUCTION IN SEMARANG REGENCY OF INDONESIA
}

\author{
Mukson, Ekowati T., Prasetyo E., Setiadi A. \\ Agribusiness Study Program, Faculty of Animal Husbandry and Agriculture, \\ University of Diponegoro, Indonesia \\ *E-mail: mukson.fapetundip@gmail.com
}

\begin{abstract}
This study aims to analyze the reinforcement factors of dairy cattle business in an effort to increase milk productivity in Semarang regency, Central Java. The research was conducted by survey and observation. The research site was determined by method of purposive sampling, based on Semarang Regency's potency as an area of development of dairy cattle in Central Java. In the study, there were two selected districts, and from each district, three groups of dairy cows were taken. Farmers as respondents were chosen by simple random sampling, with as many as ten respondents from each farmer group, making the overall respondents for these research 30 farmers from every sub-district. The primary data collection was done by interviewing dairy farmers with prepared questionnaires, while the secondary data were taken from offices and other agencies related to the research problems. Data analysis was done descriptively and statistically. Analysis of reinforcement factor was done by multiple linear regression analysis. The dependent factor $(Y)$ is milk production and independent factors consist of dairy cattle ownership (x1), number of household members $(x 2)$, business experience $(x 3)$, milk price $(x 4)$, capital $(x 5)$, business motivation $(x 6)$, forage feeding (x7) and concentrate feeding (x8). The results showed that the reinforcement factor of dairy cattle business is significant $(P<0.01)$ in affecting milk production. The cattle business needs to be strengthened through comprehensive efforts, taking into account the efficient aspects of ownership, capital support, and other business factors, so that farmers can have sustainable business.
\end{abstract}

\section{KEY WORDS}

Reinforcement factor, dairy cattle, business, increasing milk production.

Dairy cattle business is one of the most valuable animal husbandry business, since dairy products are necessary for sustenance and nutrition. The existence of dairy cattle business is vital in any society, especially in terms of family economic resouce, employment, reducing rural poverty, suppliers of industrial raw materials, providers of high-quality sources of animal food, and helping to maintain environmental sustainability by utilizing organic fertilizer produced by animals.

Dairy farming cattle business is still mostly run by farmers who are small-holders, whose production capacity and business productivity are low. The average milk dairy production rate is currently recorded only at 7-10 liters / day. Nowadays dairy farm business needs improvements which lead to productive, efficient, sustainable and profitable business. Several factors which cause low production according to Boediyana (2009) are: 1) Inefficiency due to small scale of ownership, generally taken as a sideline business; 2) unsustainable production cost to milk price ratio at the farmer level; 3) low awareness the importance of sanitation in handling milk among farmers, and 4) limited access to business load, particularly those with low interest rates.

The dairy cattle business is dominated by small scale with cattle ownership of less than 4 animals $(80.0 \%)$, of $4-7$ animals $(17.0 \%)$ and of more than 7 animals $(3.0 \%)$. This condition indicates that approximately $68 \%$ of national milk production is contributed by small animal husbandry businesses, while the rest is $28 \%$ medium businesses and $8 \%$ big 
corporations (Pradana, 2010). This condition can inhibit the production rate and ultimately affect the income level of small farmers (Pieniadz et al., 2009 and Pradana, 2010).

Nowadays, the milk intake of Milk Processing Industry (MPI) which is served by domestic production only reaches $25-30 \%$. The remaining $70 \%$ is provided by imports (Yulianto, 2011). Supply shortages are coped by means of importing, i.e. from Australia and New Zealand, in the form of raw materials of milk or as processed products ("finished product"). The value of milk imports in 2007 reached 7.9 trillion rupiahs, placed at second after poultry products, or $34.8 \%$ of the total import of animal husbandry products.

The problems in dairy cattle business are limited business capital, relatively small scale of cattle ownership, and animal feeding is still limited in quality and quantity. The management of dairy cow is still pays little attention to technical aspects of the good business practices, so the milk production level and the quality is still low. This results in minimal productivity and business efficiency. Such situation causes counterproductivity, inefficiency, low income and low business competitiveness.

Nowadays, the government has conducted a dairy revitalization program with the aim of increasing the production, and productivity of dairy cattle. Another program related to dairy development is the Presidential Regulation no. 28 in 2008 on National Industrial Policy which, among others, emphasizes the enhancement of livestock productivity, population and livestock ownership, milk quality, animal-feed improvement, human resources, partnership and cooperation with MPI, capital and increasing milk consumption. But there are still many obstacles toward business productivity, so there is a need for a strategic effort to increase the productivity of dairy cattle. This study aims to examine the factors that influence the supports of dairy cattle business in Semarang regency, Central Java.

\section{METHODS OF RESEARCH}

Milk demand continues to grow over time due to various factors, such as population growth, economic growth and awareness of the importance of nutritious food. Increased milk demand is expected to incline toward $4-5 \%$ per year on average. Based on the level of production, domestic milk has stagnated for the last 10 years, resulting in an increase in milk import rate. This condition can cause an increase in foreign exchange to meet the needs of imported milk.

Dairy cattle business is still mostly run by small-holder farmers, so the business is less attentive toward aspects of agribusiness sub-system, such as aspects of production facilities, cultivation aspects, marketing and processing aspects of the results. In addition, the scale of livestock ownership is still low, the business model is still simple in regards to animal-feed, animal-shedding, reproduction and post-harvest management (marketing). The performance of this business requires directional handling, by encouraging and strengthening all existing potentials, such as natural resources, people, technology and institutions.

Research on the reinforcement model of dairy cattle business was conducted in support of increasing milk productivity and farmer income. The research was conducted in Semarang regency, Central Java. The location of study was determined by "purposive sampling" method. Two districts of dairy cows were taken; in each sub-district, 3 farmer groups were sampled purposively, taking into account the milk production and group activities. The research was conducted by survey and observation (Singarimbun and Effendi, 1998). Determination of sample of breeder is done by simple random sampling, with 10 breeders selected from each group, so that there were 30 dairy farmers in every sub district or as a whole there were 60 samples dairy cow breeders. Primary data was taken by interview based on prepared questionnaire, identity of respondents, human resources (HR), and business management technology. The reinforcement factors of the dairy cattle business were analyzed by social conditions, economic conditions, technical expertise, etc. Variable measurements were performed using ordinal and ratio scales. The ordinal scale employed Likert scale, with five points (scores) (Indriana and Supomo, 2002), i.e. very favorable (5), favorable (4), moderate (3), unfavorable (2) and very unfavorable (1). 


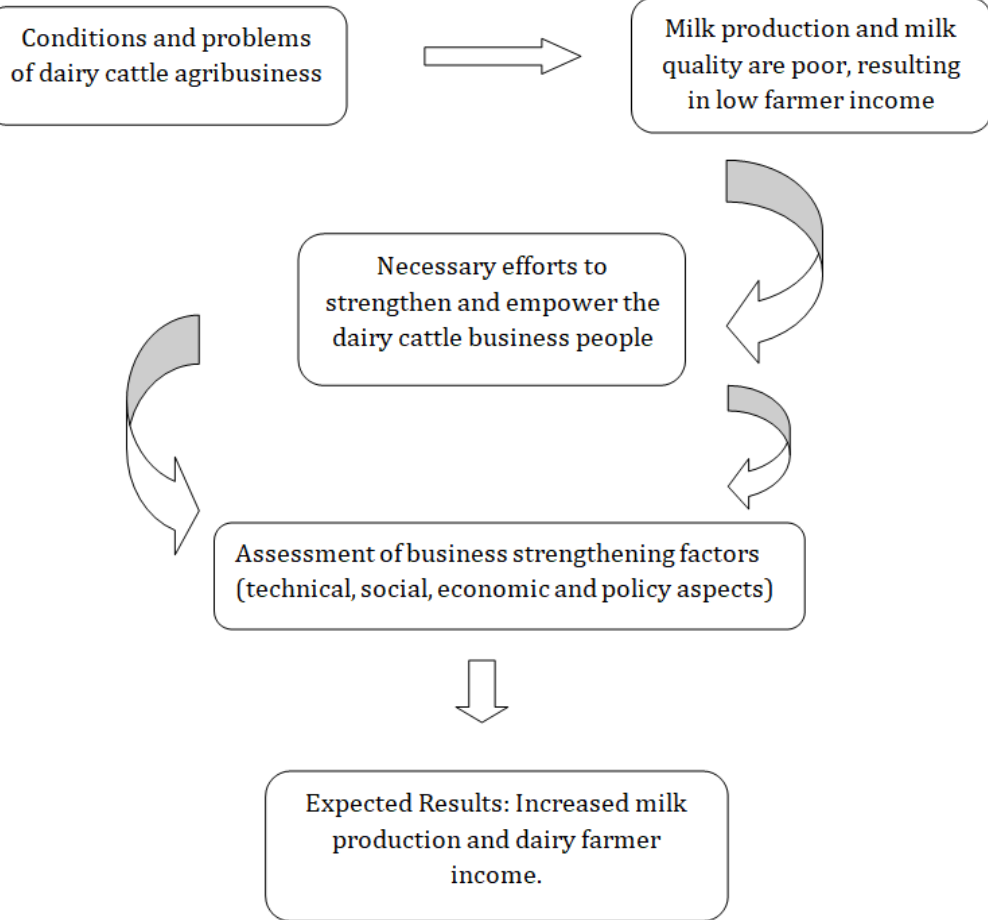

Figure 1 - Analytic Framework for Reinforcement Dairy Cattle Business

The determinants of dairy cattle business reinforcements were analyzed by multiple linear regression model (Ghozali, 2005). The dependent variable (Y) is milk productivity of breeder, while independent variables consist of business reinforcement variables including: social conditions, economic conditions, technical expertise, institutional support, and existing infrastructure. The utilized model is mathematically defined as follows:

$$
Y=a+b 1 \times 1+b 2 \times 2+b 3 \times 3+\ldots+b n \times n+e
$$

Where: $Y=$ milk productivity; $a=$ alpha constant; $b 1, b 2, b 3=$ regression coefficients; $x 1, x 2$, $\mathrm{x} 3$ and $\mathrm{xn}=$ business system variables, institutions, business systems, social, economic, technical, and policy aspect.

$F$ and $t$ tests were applied to analyze the significance of the model with $1 \%$ and $10 \%$ confidence level.

\section{RESULTS AND DISCUSSION}

General Description of Research Site. Semarang Regency is a region in Central Java that is very potential for the development of dairy cows. Based on 2013 agricultural statistics census in Semarang Regency, there were 22,408 dairy animals. Geographically, Semarang regency is bordered by Semarang City in the north, Regency of Grobogan and Demak in the east, Regency of Temanggung in the south, and Regency of Kendal in the west.

The area of Semarang Regency is $95,021 \mathrm{Ha}$. The largest land utilization is for non-rice field use, such as yard, building, moor, garden, plantation, state-forest, road, rivers, etc., which averages $75.66 \%$ and the rest are $24,34 \%$ is used for rice fields. Wetland and nonrice field (moor) areas are potential areas for the provision of livestock feeds, such as agricultural waste (straw), legume, field grass, superior grass, and other agricultural waste.

The regional temperature $\left(28.3^{\circ} \mathrm{C}\right.$ on average) is still relatively appropriate for the development of dairy cattle business, in keeping with the opinion of Sudono et al. (2003) and Toharmat (2010) which states that the air and environment are very influential on the production and productivity of dairy cattle. 
Milk production is the main goal in dairy cattle agribusiness activities. Based on milk production report, in 2013 Semarang regency produces 27,530,077 liters of milk. During 5 years (2009-2013), milk production in Semarang Regency decreased by $1.35 \%$.

Business Potential of the Development of Dairy Cattle. The development of dairy cattle population and productivity in the research site for 5 years showed that the cattle population decreased by $5.03 \%$ and milk production decreased by $6.73 \%$. The decline also occurred in Central Java level to the population of $0.46 \%$ and milk production decreased by $2.07 \%$.

Potency of dairy cow business development using $L Q$ analysis to population parameter of dairy cow, feed availability and labor absorption, indicated that $L Q$ value for dairy cow in Semarang Regency is 4.46 (base). Average availability of feed in Semarang Regency is 1.26 (base), labor absorption in Semarang Regency 4.28 (base). The three parameters used have $\mathrm{LQ}>1$ values, indicating that Semarang is a base sector and it has potential for dairy cattle development. An area is said to have a potential economic resource base if the relative proportion of a particular region's economic commodity (sector) is more specialized than the larger region (Hendarto 2002, Amalia, 2007). Production of milk is about 8.50 liters / head / day, which is still below the target of dairy revitalization. Dairy reinforcement expects milk to be produced about 15 liters per head every day.

General Overview of Respondent's Identity of Dairy Farmers. The description of respondent households of dairy cattle farmers in the study sites is categorized by age, education, main occupation and experience.

Table 1 - Dairy Cow Population Development and Milk Production in Semarang and Central Java from 2009-2013

\begin{tabular}{cccccc}
\hline No. & Year & $\begin{array}{c}\text { Dairy Cattle Population } \\
\text { in Semarang Regency } \\
\text { (head) }\end{array}$ & $\begin{array}{c}\text { Milk Production in } \\
\text { Semarang Regency } \\
\text { (liter) }\end{array}$ & $\begin{array}{c}\text { Dairy Cow Population } \\
\text { of Central Java (head) }\end{array}$ & $\begin{array}{c}\text { Milk Production of } \\
\text { Central Java (liter) }\end{array}$ \\
\hline 1. & 2011 & 36.962 & 34.761 .635 & 149.931 & 104.141 .255 \\
2. & 2012 & 39.017 & 34.386 .871 & 154.398 & 105.516 .134 \\
3. & 2013 & 22.408 & 27.530 .077 & 103.794 & 97.578 .637 \\
4. & 2014 & 27.609 & 26.129 .199 & 122.566 & 98.493787 \\
5. & 2015 & 25.789 & 25.920 .458 & 134.670 & 95.512 .925 \\
& $\mathrm{r}(\%)$ & $(5,03)$ & $(6,73)$ & $(0,46)$ & $(2,07)$ \\
\hline
\end{tabular}

Source: Department of Animal Husbandry and Animal Health of Central Java (2016)

*) Results of agricultural census ST 2013

The data showed that most dairy farmers were in the productive age category, that is from age $31-55$ years old $(73.3 \%)$, while the remaining farmers were at the age 20-30 years $(5.0 \%)$ and above 55 years $(21.7 \%)$. The productive age farmers were expected to develop the business optimally. Breeders in the productive age category were expected to have better skills to develop dairy cattle agribusiness. Based on their education levels, farmers' education levels were still relatively low. Most of the farmers $(51.7 \%)$ had elementary education, middle school education $(25.0 \%)$, senior high school degree $(16.7 \%)$ and diploma / college degree $(6.7 \%)$. The main occupations of the respondents were mostly as farmers $(40.0 \%)$, as breeders $(50.0 \%)$, the rest were traders and others by $10 \%$. Livestock and agricultural activities were closely related to rural life. This was reflected by the majority of respondents' work in the agricultural / livestock sector as the main income source of the family. The average livestock ownership was still relatively small; ownership of 1-2 animals $(80.0 \%)$, as many as $3-4$ animals $(16.67 \%)$ and $>4$ animals $(3.3 \%)$. This low livestock ownership may result in low milk production and low business efficiency. The average milk productivity level had a range of 5 - 8 liters / cow / day (38.3\%), as much as 9-12 liters $(31.7 \%)$ and $>12$ liters (30.0\%). Most respondents had long experience of being farmers, between $11-20$ years (36.7\%), over 20 years $(36.7 \%)$, and $1-10$ years $(26.6 \%)$. Dairy agribusiness activities require good management in order to increase milk production and quality, so in the long term it can be followed by improved management in terms of feeding, seeding, business management and environmental hygiene. The identity characteristics of dairy farmers can be seen in Table 2 . 
Table 2 - Respondent Characteristics of Dairy Farmers in Regency Semarang

\begin{tabular}{|c|c|c|c|}
\hline No. & Description & Amount $(n=60)$ & Percentage \\
\hline 1. & $\begin{aligned} \text { Age: } & \\
- & 20-30 \\
& \quad 31-55 \\
& -\quad>55\end{aligned}$ & $\begin{array}{l}3 \\
44 \\
13\end{array}$ & $\begin{array}{l}5,0 \% \\
73,3 \% \\
21,7 \%\end{array}$ \\
\hline 2. & $\begin{array}{cl}\text { Education Degree: } \\
\text { - } & \text { Elementary } \\
\text { - } & \text { Junior High } \\
\text { - } & \text { Senior High } \\
\text { - } & \text { College }\end{array}$ & $\begin{array}{l}31 \\
15 \\
10 \\
4\end{array}$ & $\begin{array}{l}51,7 \% \\
25,0 \% \\
16,7 \% \\
6,7 \%\end{array}$ \\
\hline 3 & $\begin{array}{cc}\text { Main Occupation: } \\
\text { - } & \text { Farmer } \\
\text { - } & \text { Breeder } \\
\text { - } & \text { Trader } \\
\text { - } & \text { Others }\end{array}$ & $\begin{array}{l}24 \\
30 \\
2 \\
4\end{array}$ & $\begin{array}{l}40,0 \% \\
50,0 \% \\
3.3 \% \\
6.7 \%\end{array}$ \\
\hline 4. & $\begin{array}{l}\text { Average of Cattle Ownership } \\
\text { Lactation: } \\
\begin{array}{ll}- & 1-2 \\
- & 3-4 \\
\text { - } & >4\end{array}\end{array}$ & $\begin{array}{l}48 \\
10 \\
2\end{array}$ & $\begin{array}{l}80,0 \% \\
16,7 \% \\
3,3 \%\end{array}$ \\
\hline 5. & 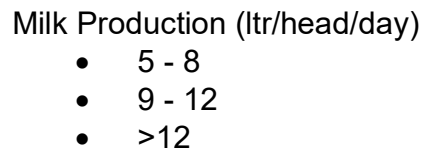 & $\begin{array}{l}23 \\
19 \\
18\end{array}$ & $\begin{array}{l}38,3 \% \\
31,7 \% \\
30,0 \%\end{array}$ \\
\hline 6. & 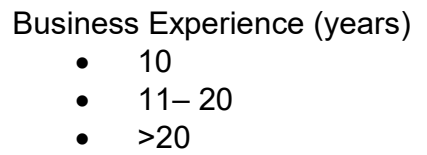 & $\begin{array}{l}16 \\
22 \\
22\end{array}$ & $\begin{array}{l}26,6 \% \\
36,7 \% \\
36,7 \%\end{array}$ \\
\hline
\end{tabular}

Reinforcement Factors of Dairy Cattle Business in Research Sites. Analysis of the factors which influence reinforcement of dairy cattle business toward milk productivity was analyzed by applying multiple linear regression model, with dependent variable $(Y=$ milk production) and independent variable consisting of ownership of dairy cattle (x1), number of household members $(x 2)$, years of business experience $(x 3)$, milk price $(x 4)$, capital $(x 5)$, business motivation $(x 6)$, forage consumption $(x 7)$ and consumption of concentrate $(x 8)$.

Table 3 - Reinforcement Factors of Dairy Cow Business in Semarang Regency

\begin{tabular}{llll}
\hline \hline No. & Reinforcement Factors & Regression Coefficient & Sign. \\
\hline 1. & Constants & 39,352 & $\left.0,000^{* *}\right)$ \\
2. & Dairy cow ownership (x1) & 2,67 & 0,435 \\
3. & Number of household member (x2) & $-0,780$ & 0,287 \\
4. & Years of business experience $(x 3)$ & $-0,169$ & 0,586 \\
5. & Milk Price (x4) & $-0,009$ & $\left.0,070^{\star}\right)$ \\
6. & Capital (x5) & 4,915 & 0,316 \\
7. & Business motivation (x6) & $-2,768$ & 0,378 \\
8. & Forage consumption (x7) & 2,231 & 0,564 \\
9. & Consumption of concentrate (x8) & $-1,170$ & $\left.0,00^{* *}\right)$ \\
& Fhit & 3,385 & \\
\hline
\end{tabular}

Note: ${ }^{* *}$ ) very significant (1\%), *) significant (10\%)

The result showed that the independent variables significantly $(P<0.01)$ affected milk production of dairy cattle. The results showed that the reinforcement of the dairy cattle business needs to pay attention to technical, economic and social aspects. According to Indraningsih and Noekman in Hutapea and Bamualim (2004), that farm household income has functional relationship with business scale and management model of various productive 
assets, such as agricultural land, capital and labor. In addition, the skill of farmers in utilizing technology will also differentiate ability to earn income.

The analysis of factors which influence reinforcement of dairy cattle business is presented in Table 2. While based on Table 3, it was observed that the factors $x 1$ up to $x 8$ together had a very significant effect on dairy cow milk production, whereas the partial variable of the number of livestock and capital has a positive and tangible influence on milk production. Capital owned by farmers was very limited, livestock ownership was limited and access to capital was constrained. These results are in line with the research of Nuraeni and Purwanto (2006) which stated that the potential of resources and income analysis of dairy cattle business in Sinjai Regency had a significant influence. The study stated that the potential of natural resources, human resources and supporting facilities affects the development of dairy cattle business. Increased capital in terms of the number of livestock ownership, operational costs and procurement of production means is expected to strengthen the current condition of dairy cattle business. The result of statistical analysis, partially for livestock ownership factor, showed that the increase of one livestock unit would increase the production of 2,666 unit liters of milk. Furthermore, capital factor analysis shows that a capital increase of 1 unit would increase milk productivity by 4,9151 units. Other independent factors (number of household members, business experience, milk price, business motivation, forage consumption and concentrate) partially had no significant effect on productivity. This condition is likely due to dairy cattle business was still managed on a sideline basis and the businesses were not geared towards commercial business. This condition is characterized by a small scale of livestock ownership and limited capital for operational support. The value of determiner coefficient (R2) of 0.4 showed that the factor which increase dairy cattle productivity was simultaneously influenced by factor $x 1$ up to $x 8$, which is equal to $40,0 \%$. The rest is equal was $60,0 \%$ and was influenced by factors outside the model.

\section{CONCLUSION AND RECOMMENDATIONS}

Based on the findings, it can be concluded that dairy cattle business in Semarang Regency has the potential for further development by taking into account the reinforcement factor of the business. The reinforcement factor of the business in increasing milk production is the increase of cattle livestock ownership and the increase of capital. Another important suggestion is increasing the ownership of dairy cattle followed by adequate capital. Some related aspects must be considered, such as technical, social, economic and policies aspect, so that the dairy cattle business can continue its growth.

\section{REFERENCES}

1- Amalia, L. 2007. Ekonomi Pembangunan. $1^{\text {st }}$ Edition, $1^{\text {st }}$ Printing. Graha IImu Press, Jakarta.

2- Boediyana, T. 2009. Pengembangan Model Usaha Agribisnis Sapi Perah dalam Upaya Peningkatan Pendapatan Usaha Kecil dan Menengah. Paper in Workshop by Ditjen P2HP, Bandung.

3- Department of Animal Husbandry and Animal Health of Central Java. 2014. Statistik Peternakan Tahun 2014. Tarubudaya, Ungaran.

4- Ghozali, I. 2005. Aplikasi Analisis Multivariate dengan Program SPSS. 4th Printing. Diponegoro University Press, Semarang.

5- Hendarto, R.M. 2000. Analisis Potensi Daerah dalam Pembangunan Ekonomi. Economy Faculty of Diponegoro University, Semarang.

6- Hutapea, Y dan A. Bamualim. 2004. Skala Usaha Tani Padi di Beberapa Lokasi Lumbung Pangan di Sumatra Selatan. Journal of Agricultural Technology Assessment and Development. PSE, Deptan, Bogor. 7 (1): $18-26$

7- Indriana, N. 2002. Metodologi Penelitian Bisnis. BPFE, Yogyakarta. 127-130. 
8- Nuraeni dan Purwanta. 2006. Potensi Sumberdaya dan Analisis Pendapatan Usaha Peternakan Sapi Perah di Kabupaten Sinjai. Agrisystem Journal. 2 (1): 8 - 17

9- Indonesia Presidential Regulation. 2008. Kebijakan Industri Nasional. Per Pres. No. 28 Tahun 2008.

10-Pieniadz, A., J.H. Hanf, D.M. Voicilas, S. Wegener, L. Gotz. 2009. Smal Farmers in the Rumanian Dairy Market: Do they Have a Future. Seminar Farms: Decline or Persistence. Rumania.

11- Pradana, M.N. 2010. Pengembangan Usaha Sapi Perah di Indonesia. BIAFS-MIBB

12- Singarimbun, M dan S. Effendi. 1989. Metode Penelitian Survai. LP3ES, Jakarta

13-Sudono, A. Rosdiana, R. Fina dan B. Setiawan. 2003. Beternak Sapi Perah Secara Intensif. Agro Media Pustaka Press, Jakarta.

14- Yulianto, H. 2011. Peningkatan Produksi dan Konsumsi Susu Segar dalam Upaya Meningkatkan Sumberdaya Manusia Berkualitas. Seminar Milk Day: Faculty of Animal Husbandry Diponegoro University, Department of Animal Husbandry and Animal Health Prov. Central Java and the Directorate General of Processing and Marketing of Agricultural Products. Ministry of Agriculture. Semarang. June 7, 2011. p: 1-5. 